\title{
A Comparative Analysis of VEGF Expression in Systemic Lupus Erythematosus with and without Nephritis
}

\author{
Dina Fathy Elessawi and Nashwa Kamal Radwan" \\ Health Radiation Research Department, National Center for Radiation Research and \\ Technology (NCRRT), Atomic Energy Authority (AEA), Cairo, Egypt.
}

\begin{abstract}
$\mathbf{T}$ HIS WORK aims at evaluating the level of Vascular Endothelial Growth Factor (VEGF) in systemic lupus erythematosus (SLE) patients and studying its association with diseasing the activity and lupus nephritis(LN). The study was carried out on 40 SLE, 40 LN patients and 20 matched controls. Plasma levels of (VEGF) expression were measured using ELISA technique. Forty SLE and $40 \mathrm{LN}$ patients with a mean age of $(31.62 \pm 8.27)$ years while 20 healthy controls were $(30.28 \pm 9.02)$ years and the SLE Disease Activity Index (SLEDAI) was $(9.1 \pm 5.5)$. In the SLE patients, anti-nuclear antibodies (ANA) was positive in $47.5 \%$ and the anti-double stranded deoxyribonucleic acid (Anti-ds DNA) was positive in $52.5 \%$ of the patients while in LN (ANA) was positive in $47.5 \%$ of patients. Anti-ds DNA was positive in $62.5 \%$. VEGA expression level was significantly increased in $\mathrm{LN}$ with mean $(470.1 \pm 369.4 \mathrm{U} / \mathrm{ml})$ compared to the SLE patients with mean $(183.54 \pm 95.03)$ with a $p$ value $(\mathrm{P}=0.0001)$. A comparative analysis between immunological and biochemical data of the SLE patients and the lupus nephritis patients show an increase in the mean levels of ESR and creatinine in lupus nephritis patients compared to the SLE patients $(\mathrm{P}<0.005)$. VEGF level in the SLE patients is not associated with skin ulcer, Oral ulcers, malar rash, arthritis, proteinuria and anemia $(\mathrm{P}<0.05)$ while in the LN patients, it statistically significant increased with skin ulcer, Oral ulcers, malar rash, arthritis and anemia $(\mathrm{P}<0.05)$. It could be concluded that VEGF level is higher in the lupus nephritis group compared to the SLE without nephritis and control groups.
\end{abstract}

Keywords: VEGF, SLE, Lupus nephritis

\section{Introduction}

Systemic lupus erythematosus (SLE) is an autoimmune disease and considered a genetically complex rheumatic disease characterized by heterogeneous clinical manifestations of unknown etiology (Aterido et al., 2017). Multiple factors are associated with the development of this disease, including genetic, racial, hormonal, and environmental factors. Immune complexes form in the microvasculature, leading to complement activation and inflammation. Moreover, antibodyantigen complexes deposit on the basement membranes of skin and kidneys (Rahman \& Isenberg, 2008). Systemic lupus erythematosus affects approximately one and a half million Americans and five million people worldwide (Weckerle \& Niewold, 2011).
The chronic generalized inflammation in SLE may involve several tissues and organs (Nasr et al., 2016). The clinical expression of SLE is the result of its complex immunopathology involving the production of autoantibodies and immune complex vasculitis with endothelial cell damage (Kuryliszyn et al., 2007).

Vascular endothelial growth factor (VEGF) is an endothelial-specific growth factor that promotes endothelial cell proliferation, differentiation and survival; it mediates endothelium-dependent vasodilatation; induces micro-vascular hyper permeability and participates in interstitial matrix remodelling (Clancy et al., 2001). In contrast to neoplastic diseases, the significance of angiogenesis and angiogenic factors in the pathogenesis of connective tissue diseases has not been very well investigated. Very few studies

"Corresponding author email: radwanashwa@yahoo.com 
have investigated the role of VEGF in adult patients with SLE, and they gave inconsistent results. Previous studies revealed abnormalities in production of VEGF and abnormal VEGF levels in the SLE patients (Carvalho et al., 2007).

Endothelial cells express VEGF, which plays a central role in the immunological reactivity (Josko et al., 2000) and is considered a key regulator of angiogenesis both in normal and pathological conditions (Ibrahim et al., 2017). The serum level of VEGF has been reported to be remarkably increased in Egyptian patients with other rheumatic diseases as systemic sclerosis (Ibrahim et al., 2011), Behçet's disease (BadrEldin \& Ibrahim, 2014) and knee osteoarthritis (Shenavandeh et al., 2017).

The overproduction of VEGF was found to be involved in the development of vasculopathy in Systemic sclerosis (Shenavandeh et al., 2017) patients. Elevated serum levels of VEGF were also observed in the SLE patients especially in cases with internal organ involvement (Kuryliszyn et al., 2007) or lupus nephritis (Ghazali et al., 2017). Polymorphism in the gene coding VEGF may be associated with increased incidence of neuropsychiatric lupus in the Egyptian SLE patients (Taha et al., 2017).

The part of VEGF in the pathogenesis of lupus nephritis has not been illustrated. Albeit both the serum level of VEGF and the titer of against DNA antibodies are hoisted in patients with lupus, they do not connect. VEGF could assume a defensive part in the conservation of organ work, most likely through support of endothelial cell capacity and uprightness of vasculature (Feliers, 2009 and Ghazali et al., 2017).

As an outcome, less VEGF would be accessible to the glomerular endothelial cells, and this could clarify endothelial cell damage and apoptosis saw in patients with lupus nephritis (Paydas et al., 2007).

Since harm to glomerular endothelial cells makes expanded presentation of the glomerular cellar layer, the course and circling DNA can tie straight forwardly to it. This could allow the flowing autoantibodies to tie glomerular storm cellar film (Ghazali et al., 2017).

The aim of the present study is to evaluate the level of Vascular Endothelial Growth Factor (VEGF) in systemic lupus erythematosus (SLE) patients and study its association with diseasing activity and lupus nephritis (LN).

\section{Patients and Methods}

The current study included one hundred patients who were classified into 3 main groups. Verbal informed consents were recruited from the outpatient clinic of Dermatology and Rheumatology departments, Faculty of Medicine Ain Shames University and the Egyptian Atomic Energy Authority in Cairo during the period from (August 2017 till January 2018). This study was approved by the Ethical Committee of the Egyptian Atomic Energy Authority and was conducted in accordance with the principle of Helsinki Declaration 1995. All patients were diagnosed clinically by two independent dermatologists and independent rheumatologists.

Patients were diagnosed according to the American College of Rheumatology (ACR) revised Criteria for the classification of SLE (Petri, 2005). Patients Exclusion criteria were as follows: diabetes, neoplasia, cigarette smoking and other autoimmune diseases e.g. rheumatoid arthritis. Full history was taken, general, local examination and Disease activity was assessed for all patients using the SLEDAI.

Laboratory investigations were carried out including the erythrocyte sedimentation rate (ESR), complete blood count (CBC), serum aspartate (AST) and alanine (ALT) transaminases, serum albumin, blood urea, serum creatinine, complete urine analysis and $24 \mathrm{~h}$-urinary proteins. ANA was assessed using immunofluorescence technique (indirect fluorescent antibody kit ANAFAST TM, No's1670, 6670, 1680) and antidsDNAantibody by enzyme linked immunosorbent assay (ELISA) (using anti-dsDNA ELISA kit No. 7100). Quantitative measurement of VEGF gene expression was performed using ELISA (QUANTA Lite ${ }^{\mathrm{TM}}$ Chromatin ELISA)

\section{Statistical analysis}

Data were statistically described in terms of mean $( \pm \mathrm{SD})$ and range or frequencies and percentages when appropriate. A comparison of numerical variables between the study groups was done using Mann-Whitney $U$ for independent samples. Chi-square test was performed 
for comparing categorical data. Correlation between various variables was carried out using Spearman rank correlation equation. All statistical calculations were conducted using SPSS version 15 for Microsoft Windows. Significant values were set at $\mathrm{P}<0.05$.

\section{Result}

One hundred participants were included in the present study, they were classified into 3 main groups:

Group I: 40 SLE Egyptian inpatients and/or outpatients without nephritis with a mean age of $(31.62 \pm 8.27)$ years, were attending the clinics of the Faculty of Medicine, Ain Shames University and the Egyptian Atomic Energy Authority in Cairo.

Group II: 40 LN Egyptian inpatients and/ or outpatients with a mean age of $(31.62 \pm 8.27)$ years, were attending the clinics of the Faculty of Medicine Ain Shams University and the Egyptian Atomic Energy Authority in Cairo.

Group III: 20 Egyptian healthy controls with a mean age of $(30.28 \pm 9.02)$ years.

There is a significant difference in clinical manifestations between SLE and LN groups. The clinical features of the SLE patients with and without nephritis are shown in Fig. 1 and Table 1.

TABLE 1. The clinical features of the SLE patients with and without nephritis.

\begin{tabular}{lcccc}
\hline \multirow{2}{*}{ Clinical manifestations } & $\begin{array}{c}\text { SLE } \\
\text { No.=40 }\end{array}$ & $\begin{array}{c}\text { Lupus nephritis } \\
\text { No.=40 }\end{array}$ & \multicolumn{2}{c}{ Chi-square test } \\
\hline Fever & $11(27.5 \%)$ & $10(25 \%)$ & 0.056 & P-value \\
Oral Ulcers & $15(37.5 \%)$ & $10(25 \%)$ & 1.455 & 0.798 \\
Malar Rash & $19(47.5 \%)$ & $16(40 \%)$ & 0.457 & 0.499 \\
Psychosis & $2(5 \%)$ & $1(2.5 \%)$ & 0.346 & 0.556 \\
Depression & $2(5 \%)$ & $1(2.5 \%)$ & 0.346 & 0.556 \\
Headache & $4(10 \%)$ & $5(12.5 \%)$ & 0.125 & 0.723 \\
Myositis & $4(10 \%)$ & $6(15 \%)$ & 0.457 & 0.499 \\
Arthritis & $17(42.5 \%)$ & $19(47.5 \%)$ & 0.202 & 0.653 \\
Pleural Effusion & $2(5 \%)$ & $0(0 \%)$ & 2.051 & 0.152 \\
Skin Ulcer & $6(15 \%)$ & $10(25 \%)$ & 1.250 & 0.263 \\
\hline
\end{tabular}

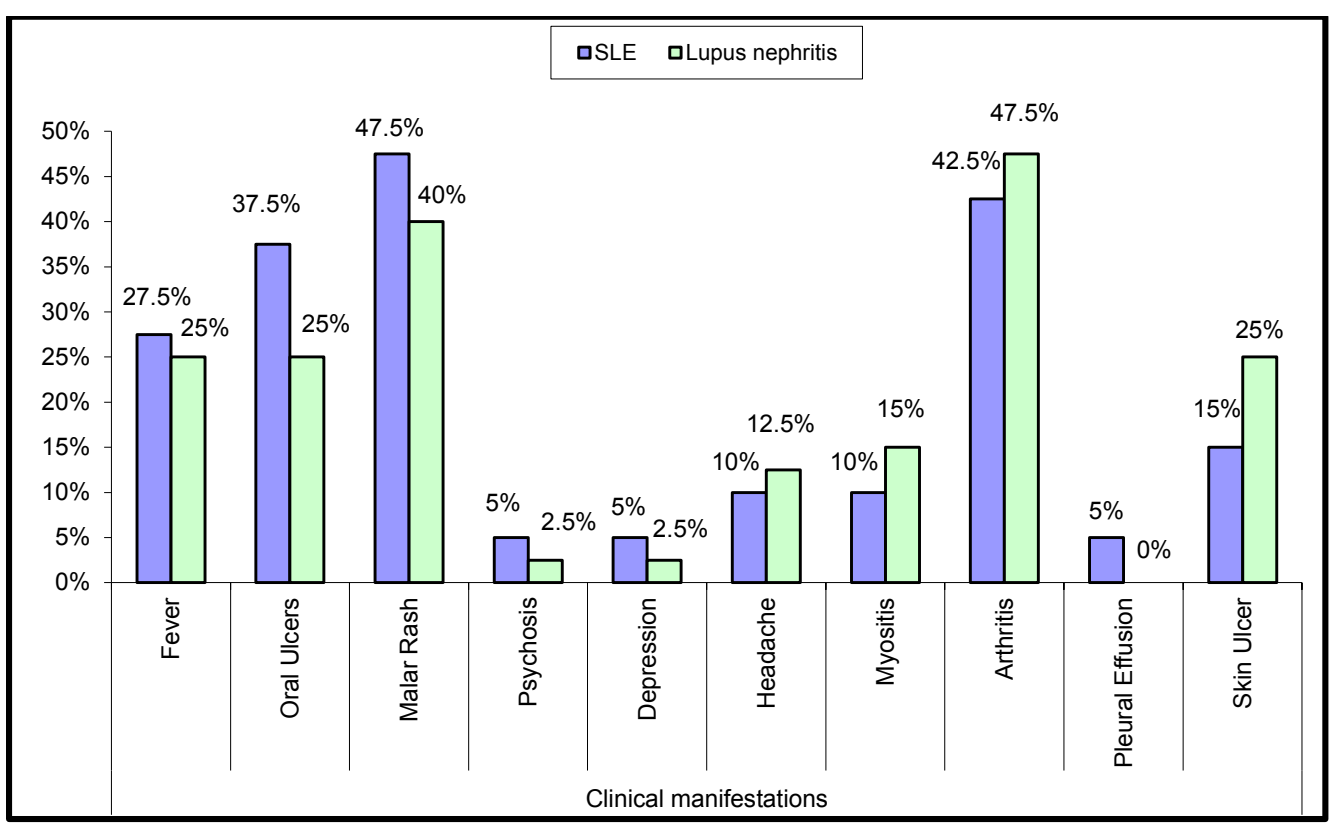

Fig. 1. The clinical features of the SLE patients with and without nephritis. 
The immunological and biochemical data of the SLE patients and control show that there was a significant increase in the mean levels of ESR and creatinine in SLE patients compared to the control group $(\mathrm{P}<0.001)$. Also, a significant decrease in the mean levels of $\mathrm{Hb}, \mathrm{C} 3$ and $\mathrm{C} 4$ was observed in the SLE patients compared to the control group $(\mathrm{P}<0.001)$.

The immunological and biochemical data of the lupus nephritis patients and control reveals that there was a significant increase in the mean levels of ESR and creatinine in lupus nephritis patients compared to the control group $(\mathrm{P}<0.001)$. There was a significant decrease in the mean levels of $\mathrm{Hb}$, platelets, $\mathrm{C} 3$ and $\mathrm{C} 4$ observed in lupus nephritis patients compared to the control group $(\mathrm{P}<0.001)$.

There was a significant increase in the mean levels of ESR and creatinine in lupus nephritis patients compared to the SLE patients $(\mathrm{P}<0.001)$. There was a significant decrease in the mean levels of $\mathbf{C} 3$ and $\mathbf{C} 4$ observed in lupus nephritis patients compared to the SLE patients $(\mathrm{P}<0.001)$ as shown in Table 2.
When compared comparison is held between ANAs and Anti-ds DNA of the SLE patients and control, there was a significant association in the level of ANAs and Anti-ds DNA of the SLE patients $(47.5 \%)$ and $(52.5 \%)$ respectively $(\mathrm{P}$ value 0.0001$)$.

Also, when ANAs and Anti-ds DNA of the lupus nephritis patients and the control are compared, there was a significant association in the level of ANAs and Anti-ds DNAof the SLE patients $(47.5 \%)$ and $(62.5 \%)$, respectively $(\mathrm{P}$ value 0.000$)$.

VEGF protein value was classified according to clinical and laboratory data in SLE patients. A comparison between VEGF protein level regarding immunological and biochemical data shows a statistically significant increase in skin ulcer, oral ulcers, malar rash, arthritis, and anemia in lupus nephritis patients $(\mathrm{p}<0.05)$ as shown in Table 3.

VEGF protein values are shown in Table 4 and Fig. 2, VEGF level was higher in lupus nephritis compared to the SLE patients without nephritis and control groups with P value (0.001).

TABLE 2. Comparison between immunological and biochemical data of the lupus nephritis patients and SLE patients.

\begin{tabular}{lccc}
\hline & Lupus nephritis & SLE \\
\cline { 2 - 4 } & Mean \pm SD & Mean \pm SD & P value \\
\hline $\mathrm{Hb}$ & $10.15 \pm 1.71$ & $9.79 \pm 1.17$ & 0.418 \\
$\mathrm{WBCs}$ & $5.47 \pm 0.90$ & $5.67 \pm 1.68$ & 0.665 \\
platelets & $232.37 \pm 62.98$ & $271.15 \pm 85.39$ & 0.027 \\
ESR & $52.40 \pm 14.46$ & $42.68 \pm 21.63$ & 0.004 \\
Creatinine & $3.60 \pm 1.64$ & $0.96 \pm 0.45$ & $<0.001$ \\
$\mathrm{C} 3$ & $32.33 \pm 30.21$ & $67.77 \pm 50.39$ & 0.003 \\
$\mathrm{C} 4$ & $5.21 \pm 151$ & $14.49 \pm 12.32$ & $<0.001$ \\
\hline
\end{tabular}

TABLE 3. Comparison between VEGF protein level regarding immunological and biochemical data of the SLE patients and lupus nephritis patients.

\begin{tabular}{lccccc}
\hline $\begin{array}{l}\text { Clinical and laboratory } \\
\text { data }\end{array}$ & \multicolumn{2}{c}{ Mean } & \multicolumn{2}{c}{ Standard deviation } & \multirow{2}{*}{ P value } \\
\cline { 2 - 4 } & Lupus nephritis & SLE & Lupus nephritis & SLE & \\
\hline Skin ulcer & 269.15 & 137.07 & 115.90 & 50.29 & 0.017 \\
Oral ulcer & 266.05 & 159.21 & 117.16 & 77.62 & 0.007 \\
Malar rash & 250.87 & 182.00 & 102.78 & 95.02 & 0.020 \\
Arthritis & 272.62 & 179.66 & 100.01 & 97.49 & 0.007 \\
Proteinuria & 271.96 & 224.35 & 111.46 & 108.97 & 0.595 \\
Anemia & 250.09 & 157.13 & 108.51 & 85.76 & 0.001 \\
\hline
\end{tabular}


TABLE 4.Correlation of VEGF protein value in lupus nephritis with SLE and control groups.

\begin{tabular}{cccccccccc}
\hline & & SLE & Lupus nephritis & Control & Test value & P-value & P1 & P2 & P3 \\
\hline \multirow{2}{*}{ VEGF } & Mean $\pm \mathrm{D}$ & $179.31 \pm 95.27$ & $260.18 \pm 112.29$ & $100.06 \pm 14.33$ & 20.551 & 0.000 & 0.001 & 0.003 & 0.001 \\
\hline
\end{tabular}

*: Independent t-test

NS: Non significant; S: significant; HS: Highly

P1: SLE group VS Lupus nephritis group

P2: SLE group VS Control

P3: Lupus nephritis group VS Control

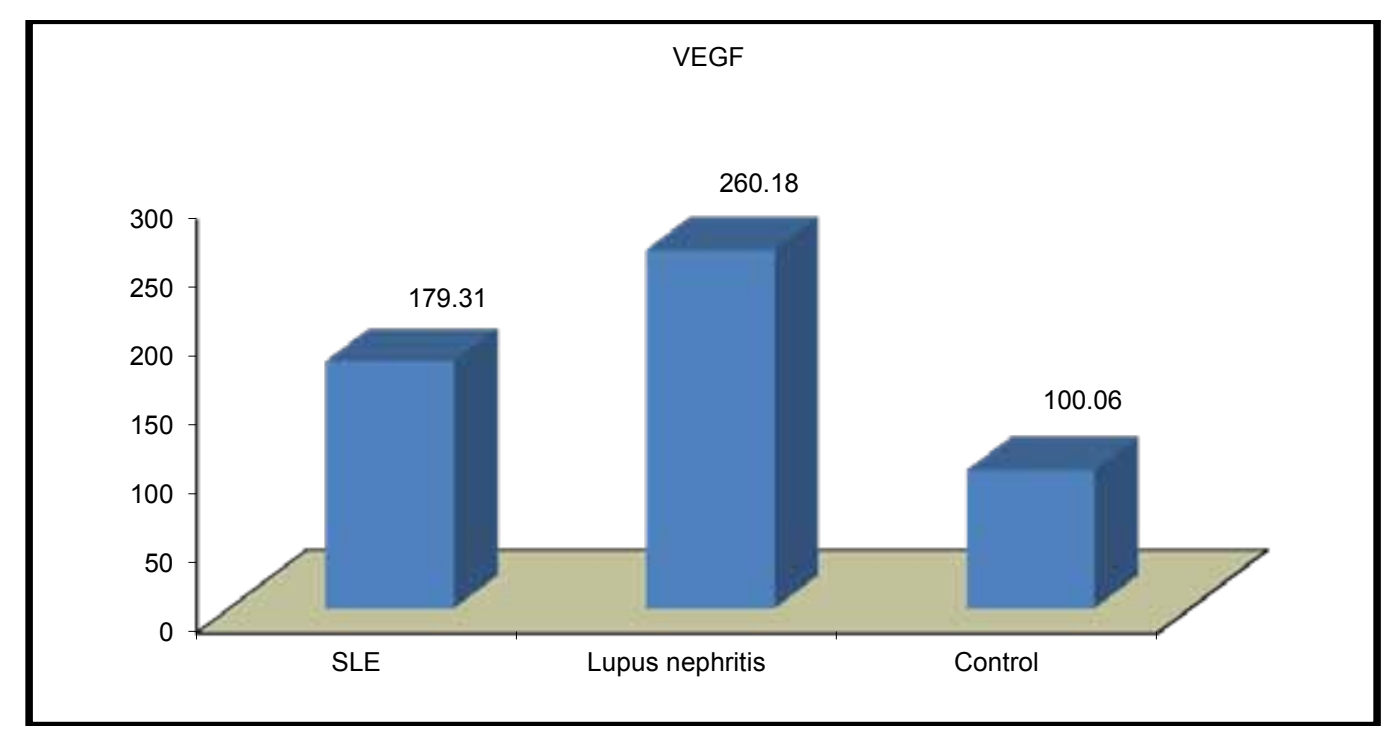

Fig. 2. VEGF protein value in lupus nephritis, SLE (A) and control (AB) groups.

\section{Discussion}

Systemic lupus erythematosus had been repeatedly described with significant geographic and racial variations. This disease is mostly seen in females, with the younger women being mostly affected (Ahmed et al., 2017). SLE can affect any part of the body including the heart, joints, skin, lungs, blood vessels, liver, and nervous system and LN (Sui et al., 2013). SLE is characterized by the generation of autoantibodies predominantly directed against nuclear proteins and nucleic acids (Bravo et al., 2015). One of the immunological hallmarks of SLE is the loss of tolerance to self-chromatin, manifesting as circulating autoantibodies directed against three of its major subunits, namely, ds-DNA, histones, and nucleosomes (Koutouzov et al., 2004) and because of the heterogeneous nature of lupus, it has been challenging to identify markers that are sensitive and specific enough for its diagnosis and monitoring (Vasquez et al., 2017).
Deoxyribonucleic acid is a major component of the serum nucleosome in SLE patients and its potential contribution is through apoptosis, necrosis and Neutrophil extracellular traps, induced apoptosis (NETosis) (Pisetsky, 2012).

In this study, VEGF level was higher in lupus nephritis patients compared to the SLE patients without nephritis and the control groups $(\mathrm{P}<$ $0.001)$. This was in accordance with Feliers et al. (2009) who reported that the serum VEGF levels were higher in lupus nephritis patients. In addition, Yajuan et al. (2013) considered the serum VEGF levels one of biomarkers of lupus nephritis .This agrees with Heshmat \& El-Kerdany (2007) who stated that VEGF significantly increased in the Egyptian SLE adolescent patients with renal and neurologic involvement while the level was comparable between those with and without arthritis. Also, the SLE patients with mucocutaneous and articular manifestations or nephritis tended to have a higher serum VEGF 
level compared to those without. VEGF was significantly higher in those with cutaneous manifestations than those without (Moneib et al., 2012). Similarly, VEGF was reported to be increased in patients with LN compared to those without and to the control (Navarro et al., 2002 and Ghazali et al., 2017). Two previous studies compared serum VEGF level between the LN and non-LN SLE patients with the controls from a normal population and showed a significant difference in serum VEGF between these three groups. (Petri et al., 2012 and Heshmat et al., 2007).

The SLE patients showed a significant decrease in the mean level of $\mathrm{Hb}$ than the control group $(\mathrm{P}<0.001)$. This may be due to the poor general condition and anorexia leading to inadequate feeding or the cytotoxic therapy that may suppress erythroid precursors in the bone marrow, autoimmune hemolytic anemia caused by autoantibodies directed against RBC antigens and detected by coomb's test is the most significant in acute SLE (Voulgarelis et al., 2000). The mean ESR was significantly higher in SLE patients than control group $(\mathrm{P}<0.001)$ which correlates with (Stockmann et al., 2008). This is due to the presence of inflammatory changes in SLE.

ANA and anti-ds-DNA was highly positive in the SLE patients and negative in all the controls. A high angiogenic activity was found to be associated with renal complications in the SLE patients (Sakly et al., 2009). Gheita et al. (2018) mentioned that the serum VEGF level was significantly higher in those with a positive anti-ds DNA compared to those with a negative test especially those with musculoskeletal manifestations. A high angiogenic activity was found to be associated with the presence of anti- dsDNA antibodies in the SLE patients (Sakly et al., 2009).

The mean complement C3 and complement C4 levels were significantly lower in the SLE patients than the control subjects. These results agree with those of Abdellatif et al. (2010) and Bhattacharya et al. (2011) who explained this by the consumption of the complement $\mathrm{C} 3$ and $\mathrm{C} 4$ in immune complex formation and by reduced synthesis.

Also, this is in accordance with Javier et al. (2012) who studied the serum levels of VEGF which determined by an enzyme-linked immunosorbent assay in 47 SLE patients and in 30 healthy controls and reported significant differences in VEGF serum concentration between SLE patients with and controls $(\mathrm{P}<0.01)$ and Heshmat \& El-Kerdany (2007) who studied 30 patients and 15 healthy controls that were evaluated for VEGF serum levels, and reported that VEGF serum levels were significantly higher in the SLE patients than the controls $(\mathrm{P}<0.0001)$.

Different studies confirm the association between VEGF level with many diseases (Bozduman et al., 2016). VEGF serum levels were assessed in 47 Psoriatic patients and 40 controls using ELISA test, and it was noted that a significant increase in serum levels of VEGF in patients with psoriasis $(\mathrm{P}=0.008)$ compared with the healthy controls has occurred.

As for the clinical and laboratory manifestations (malar rash, skin ulcer, oral ulcer, arthritis and anemia), VEGF serum levels were significantly higher in lupus nephritis patients compared to the SLE patients without nephritis $(\mathrm{P}<0.05)$. These results agree with Robak et al. (2003) who reported that The VEGF level was higher in the active SLE patients than in the inactive SLE patients $(\mathrm{P}<0.05)$.

In the lupus nephritis patients, VEGF protein level was significantly higher with VEGF $(\mathrm{P}<$ 0.001 ), this concurs with the study conducted by Syamimee et al. (2017) that could not demonstrate any significant association between VEGF polymorphism with VEGF level in the plasma that has been shown to be associated with elevated levels of VEGF. This was in accordance with Avihingsanon et al. (2009), while concurs with the study performed by Moskal et al. (2007) who observed the association between elevated serum VEGF levels in the SLE patients (Syamimee et al., 2017).

\section{Conclusion}

There was an association between VEGF expression and SLE susceptibility especially with lupus nephritis patients.

\section{Funding}

This research did not receive any specific grant from funding agencies in the public, commercial, or not-for-profit sectors. 


\section{References}

Abdellatif, A.A., Waris, S., Lakhani, A., Kadikoy, H., Haque, W. and Truong, L.D. (2010) True vasculitis in lupus nephritis. Clin Nephrol. 74(2), 106-12.

Ahmed, N., Shigidi, M., AlAgib, A., Abdelrahman, H. and Elshafie, T. (2017) Clinical features and antinuclear antibodies profile among adults with systemic lupus erythematosus and lupus nephritis: a cross-sectional study. Pan. Afr. Med. J. 27, 114. Published online Jun 14. DOI: 10.11604/pamj.2017.27.114.5981

Aterido, A., Julià, A., Carreira, P., Blanco, R., LópezLongo, J.J. and Venegas, J.J.P., et al. (2017) Genomewide pathway analysis identifies VEGF pathway association with oral ulceration in systemic lupus erythematosus. Arthritis Res. Ther. 19(1), 138.

Avihingsanon, Y., Benjachat, T., Tassanarong, A., Sodsai, P., Kittikovit, V. and Hirankarn, N. (2009) Decreased renal expression of vascular endothelial growth factor in lupus nephritis is associated with worse prognosis. Kidney International, 75, 1340-1348.

BadrEldin, A. and Ibrahim, A. (2014) Assessment of the relationship between vascular endothelial growth factor and cardiovascular involvement in Egyptian patients with Behçet's disease. Egypt Rheumatol. 36(3), 131-7

Bhattacharya, A., Soni, S., Jain, R. and Tiwari, P. (2011) Systemic lupus erythematosus. Pharmacologyonline, 3, 812-825.

Bozduman, T., Evans, S.E., Karahan, S., Hayran, Y., Akbiyik, F. and Lay, I. (2016) Genetic Risk Factors for Psoriasis in Turkish Population: $-1540 \mathrm{C} / \mathrm{A}$, -1512 Ins18, and $+405 \mathrm{C} / \mathrm{G}$ Polymorphisms within the Vascular Endothelial Growth Factor Gene. Ann. Dermatol. Feb. 28(1), 30-39.

Bravo-Zehnder, M., Toledo, E.M., Segovia-Miranda, F., Serrano, F., Benito, M.J. and Metz, C., et al (2015) Anti-ribosomal $\mathrm{P}$ protein autoantibodies from patients with neuropsychiatric lupus impair memory in mice. Arthritis Rheumatol. 67(1), 204-214.

Carvalho, J.F., Blank, M. and Shoenfeld, Y. (2007) Vascular endothelial growth factor (VEGF) in autoimmune disease. J. Clin. Immunology. 27(3), 246-256. [PubMed]

Clancy, R., Marder, G. and Martin, V., et al. (2001)
Circulating activated endothelial cells in systemic lupus erythematosus. Further evidence for diffuse vasculopathy. Arth. Rheum. 44, 1203-1208. [PubMed]

Feliers, D. (2009) Vascular endothelial growth factor as a prognostic marker of lupus nephritis. Kidney International, 75, 1251.

Gheita, T.A., Abaza, N.M., Hammam, N., Mohamed, A.A.A., El-Gazzar, I.I. and Eissa, A.H. (2018) AntidsDNA titre in female systemic lupus erythematosus patients: relation to disease manifestations, damage and antiphospholipid antibodies. Lupus, 2018 Jan;1. 961203318760209.

Ghazali, W., Iberahim, R. and Ashari, N.S.M. (2017) Serum vascular endothelial growth factor (VEGF) as a biomarker for disease activity in Lupus nephritis. Malays J. Med. Sci. 24(5), 62-72.

Heshmat, N.M. and El-Kerdany, T.H. (2007) Serum levels of vascular endothelial growth factor in children and adolescents with systemic lupus erythematosus. Pediatric Allergy and Immunology, 18, 346 .

Ibrahim, S.E., Elshishtawy, H.F., Samy, A.H. and Galald, Z.A.(2011) Role of vascular endothelial growth factor and monocyte chemoattractant protein-1 in Behçet's disease. Indian J. Rheum. 6(4), 168-72.

Ibrahim, S.E., Morad, C.S., Farouk, N. and Louis, A. (2017) Platelet indices as markers of inflammation in systemic sclerosis patients: relation to vascular endothelial growth factor and flow mediated dilatation. Egypt. Rheumatol. epub .

Javier, R.C., Catuxa, P., Banesa, D.P. and Patricia, L., et al. (2012) Circulating endothelial cells and their progenitors in systemic lupus erythematosus and early rheumatoid arthritis patients. Rheumatology, 51(10).

Josko, J., Gwozdzb, B., Jedrzejowska-Syzpulka, H. and Hendryk, S. (2000) Vascular endothelial growth factor (VEGF) and its effect on angiogenesis. Med. Sci. Monit. 6, 1047-52.

Koutouzov, S., Jeronimo, A.L., Campos, H. and Amoura, Z. (2004) Nucleosomes in the pathogenesis of systemic lupus erythematosus. Rheum. Dis. Clin. N Am. 30, 529-558. 
Kuryliszyn, M.A., Klimivk, P.A., Sierakowski, S. and Ciolkiewicz, M. (2007) Vascular endothelial growth factor in SLE: relationship to disease activity, systemic organ manifestations, and nail fold capillaroscopic abnormalities. Arch. Immunol. Ther. Exp. 55(3), 179-85.

Moneib, H.A., Salem, S.A., Aly, D.G., Khedr, H.T., Wafaey, H.A. and Hassan, H.E. (2012) Assessment of serum vascular endothelial growth factor and nail fold capillaroscopy changes in systemic lupus erythematosus with and without cutaneous manifestations. J. Dermatol. 39(1), 52-7.

Moskal, A.K., Klimiuk, P.A., Sierakowski, S. and Ciołkiewicz, M. (2007) Vascular endothelial growth factor in systemic lupus erythematosus: relationship to disease activity, systemic organ manifestation, and nailfold capillaroscopic abnormalities Arch Immunol Ther. Exp. (Warsz). Jun, 55(3), 179-185.

Nasr, A.S., Fawzy, S.M., Gheita, T.A. and El-Khateeb, E. (2016) Expression of Toll-like receptors 3 and 9 in Egyptian systemic lupus erythematosus patients. $Z$. Rheumatol. 75(5), 502-7.

Navarro, C., Candia-Zuniga, L., Silveira, L.H., Ruiz, V., Gaxiola, M., Avila, M.C. and Amigo, M.C. (2002) Vascular endothelial growth factor plasma levels in patients with systemic lupus erythematosus and primary antiphospholipid syndrome. Lupus, 11, 21.

Paydas, S., Balal, M., Tanriverdi, K., Sertdemir, Y. and Baslamisli, F. (2007) The relationship between the VEGF levels and VEGF mRNA expression and clinical course in different glomerulonephritis. Renal Failure, 29, 779.

Petri, M, (2005) Review of classification criteria for systemic lupus erythematosus. Rheum. Dis. Clin. North Am. May, 31(2), 245-54

Petri, M., Orbai, A.M., Alarcon, G.S., Gordon, C., Merrill, J.T. and Fortin, P.R., et al. (2012) Derivation and validation of the systemic lupus international collaborating clinics classification criteria for systemic lupus erythematosus. Arthritis Rheum. 64, 2677-2686.

Pisetsky, D.S. (2012) The DAMP Clin origin and properties of extracellular DNA: from PAMP to DAMP. Clin, Immunol. Jul, 144(1), 32-40. DOI: 10.1016/j.clim.2012.04.006.
Rahmanm, A. and Isenberg, D.A. (2008) Systemic lupus erythematosus . N. Engl. J. Med. 358(9), 929-39.

Robak, E., Jedrzejewska, A.S. and Robak, T. (2003) Vascular endothelial growth factor and its soluble receptors VEGFR-1 and VEGFR-2 in the serum of patients with systemic lupus erythematosus. Mediators Inflamm. Oct. 12(5), 293-298.

Sakly, N., Mirshahi, P., Ducros, E., Soria, J., Ghedira, I. and Mirshahi, M. (2009) Angiogenic activity in sera of patients with systemic lupus erythematosus. Lupus, 18(8), 705-12.

Shenavandeh, S., Tarakemeh, T., Sarvestani, E.K. and Nazarinia, M.A. (2017) Serum vascular endothelial growth factor (VEGF), soluble VEGF receptor-1 (sVEGFR-1) and sVEGFR-2 in systemic sclerosis patients: relation to clinical manifestations and capillaroscopy findings. Egypt. Rheumatol. 39(1), 19-24.

Stockmann, C., Doedens, A., Weidemann, A., Zhang, N., Takeda, N., Greenberg, J.I., Cheresh, D.A. and Johnson, R.S. (2008) Deletion of vascular endothelial growth factor in myeloid cells accelerates tumorigenesis. Nature, 456(7223), 814-818.

Sui, M., Lin, Q., Xu, Z., Han, X., Xie, R. and Jia, X. et al. (2013) Simultaneous positivity for anti-DNA, antinucleosome and anti-histone antibodies is a marker for more severe lupus nephritis. J. Clin. Immunol. 33, 378-387.

Syamimee, W., Ghazali, W., Iberahim, R., Suryani, N. and Ashari, M. (2017) Serum vascular endothelial growth factor (VEGF) as a biomarker for disease activity in lupus nephritis. Malays J. Med. Sci. Oct, 24(5), 62-72. Published online Oct 3.

Taha, S., Gamal, S.M., Nabil, M., Naeem, N., Labib, D., Siam, I. and Gheita, T.A. (2017) Vascular endothelial growth factor G1612A (rs10434) gene polymorphism and neuropsychiatric manifestations in systemic lupus erythematosus patients. Rev. Bras. Reumatol. Engl. Ed. 57(2), 149-53.

Vasquez, C.N., Wahezi, D. and Putterman, C. (2017) Diagnostic and prognostic tests in systemic lupus erythematosus. Best Pract. Res. Clin. Rheumatol. 31(3), 351-63.

Voulgarelis, M., Kokori, S.I., Loannidis, J.P., Tzioufas, A.G., Kyriaki, D. and Moutsopoulos, H.M. 
(2000) Anemia in systemic lupus erythematosus: Aetiological profile and the role of erythropoietin. Ann. Rheum. Dis. 59, 217-222.
Yajuan, Li., Xiangdong, F. and Quan-Zhen, Li. (2013) Biomarker profiling for lupus nephritis . Genomics Proteomics Bioinformatics. Jun, 11(3), 158-165.

Weckerle, CE. and Niewold, T.B. (2011) The unexplained female predominance of systemic (Received 17/11/2018; lupus erythematosus: clues from genetic and cytokine studies. Clin. Rev. Allergy Immunol. 40(1), accepted $19 / 12 / 2018)$

\section{تحليل مقارن لعامل نمو بطانة الاوعية الدموية في الأئبة الحمراء مع و بدون ألتهاب الكليه \\ نشوة كمال رضوان و دينا فتحي العيسوي \\ قسم البحوث الصحية الاشعاعية ـ المركزئ القو مى لبحوث و و تكنولوجيا الاشعاع ـ هيئة الطاقة الذرية ـ القاهرةـ}

الذئبة الحمامية هو مرض معقد شائع يتميز بالألتهاب المزمن المعمم الذي قد ينطوي على العديد من الأنسجة

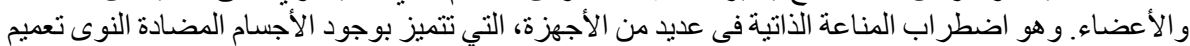

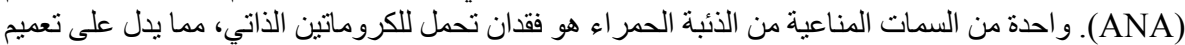

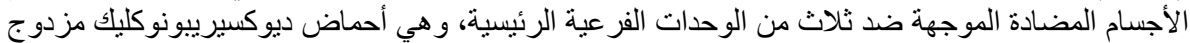

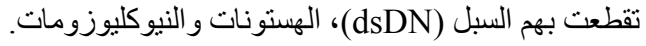

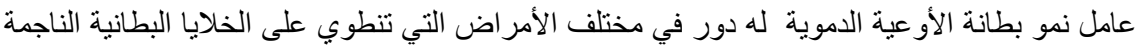

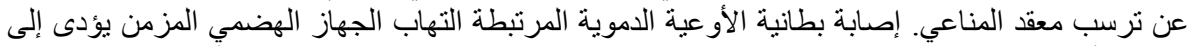

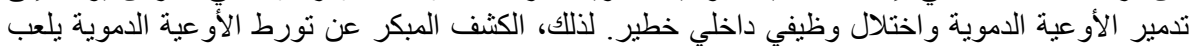

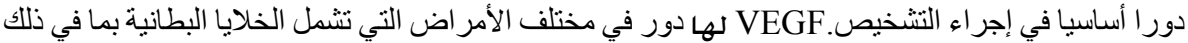
التهاب الكلى الذئبة الناجمة عن ترسب معقد المناعي.

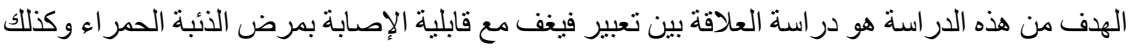

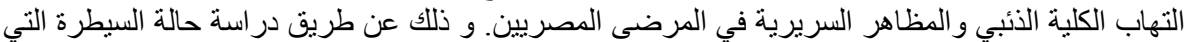

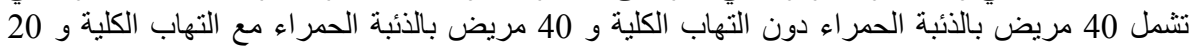
الضو ابط الصحية. نم تقييم نشاط المرض باستخدام مؤشر نشاط مرض الذئبة الحمر اء (SLEDAI) وقياس

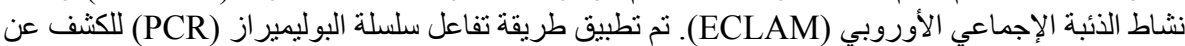

VEGF

و كانت النتائج أن 40 مريض الذئبة الحمر اء بدون التهاب الكلية مع متوسط عمر (82. (82.62 (31.62 (8.27) سنة،

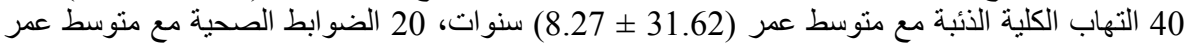

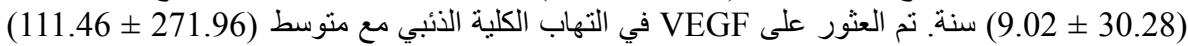

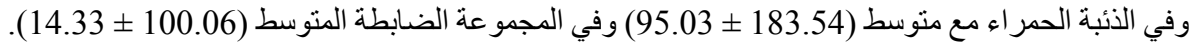

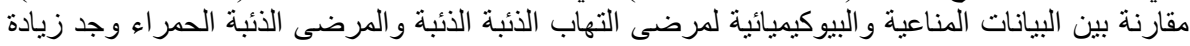

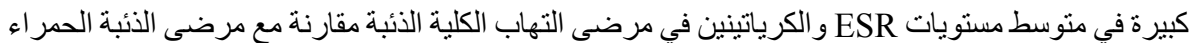
(P<0.005) و انخفاض في C3 و C4 في مرضى التهاب الكلية الذئبة بالمقارنة مع مرضى الذئبة الحمر اء 